\title{
Anthropometric and Metabolic Parameters in 46 Hypogonadal Men with Obesity Grade III Improve upon Long-Term Treatment with Testosterone Undecanoate (TU) Injections: Observational Data from Two Registry Studies
}

Saad F,2, Haider $A^{3}$, Yassin A4, Doros $G^{5}$, Traish A6

${ }^{1}$ Global Medical Affairs Andrology, Bayer Pharma, Berlin, Germany

${ }^{2}$ Gulf Medical University, Ajman, UAE

3Private Urology Practice, Bremerhaven, Germany

Institute of Urology and And rology, Norderstedt, German

5 Department of Epidemiolt

Department of Epidemiology and Statistics, Boston University School of Public Health, Boston, Mass, USA

Introduction

Numerous studies have reported inverse associations between testosterone and obesity as well as other components of the metabolic syndrome.

Methods

From two registry studies of 561 hypogonadal men, 46 men with obesity grade III (BMI $\left.\geq 40 \mathrm{~kg} / \mathrm{m}^{2}\right)$ were selected.

All patients received TU injections for up to 6 years. 46 men were followed for two years, 43 for three years, 37 for four years, 34 for five years, and 24 for six years. Declining numbers are result of the registry design.

Results

Weight $(\mathrm{kg})$ decreased from $129.02 \pm 5.67$ to $103.33 \pm 4.17$, mean change from baseline $-27.15 \pm 0.74 \mathrm{~kg}$, percent change from baseline $-20.99 \pm 3.16 \%$. Waist circumference $(\mathrm{cm})$ decreased from $118.41 \pm 5.69$ to $106.48 \pm 4.91$, mean change from baseline $12.44 \pm 0.36 \mathrm{~cm}$. BMI $\left(\mathrm{kg} / \mathrm{m}^{2}\right)$ decreased from $41.93 \pm 1.5$ to $33.62 \pm 1.58$, mean change from baseline -8.79 $\pm 0.23 \mathrm{~kg} / \mathrm{m}^{2}$.

Mean fasting glucose $(\mathrm{mg} / \mathrm{dl})$ decreased from $115.48 \pm 23.85$ to $96.54 \pm 2.9(p<0.0001)$, mean change from baseline $-18.48 \pm 2.96 \mathrm{mg} / \mathrm{dl}, \mathrm{HbA} \mathrm{Ac}_{\mathrm{c}}(\%)$ from $7.57 \pm 1.38$ to $6.08 \pm 0.5$, mean change from baseline $-1.61 \pm 0.13 \%$.

Total cholesterol (TC; $\mathrm{mg} / \mathrm{dl}$ ) decreased from $306.76 \pm 43.03$ to $192.23 \pm 9.17$ ( $p<0.0001)$, LDL ( $\mathrm{mg} / \mathrm{dl}$ ) from $190.57 \pm 36.6$ to $136.24 \pm 28.07(p<0.0001)$, triglycerides $(\mathrm{mg} / \mathrm{dl})$ from $326.87 \pm$ 60.21 to $194.4 \pm 12.59(\mathrm{p}<0.0001)$. HDL ( $\mathrm{mg} / \mathrm{dl})$ increased from $62.76 \pm 18.7$ to $72.55 \pm 13.34(p<0.0001)$. The TC: HDL ratio declined from $5.47 \pm 2.57$ to $2.75 \pm 0.59$ ( $p<0.0001)$.

Systolic blood pressure $(\mathrm{mmHg})$ decreased from $161.04 \pm 14.3$ to $142.05 \pm 9.57$, diastolic blood pressure from $97.07 \pm 10.91$ to $80.89 \pm 6.76$.

Liver enzymes AST and ALT (U/L) decreased from $42.39 \pm 17.84$ to $20.33 \pm 1.9$ and from $43.52 \pm 20.68$ to $20.43 \pm 2.75$, respectively ( $<<0.0001$ for both), suggesting a reduction in liver fat content.

C-reactive protein (CRP, $\mathrm{mg} / \mathrm{L})$ declined from $3.96 \pm 4.31$ to $0.57 \pm 0.59(p<0.0001)$.

There were no drop-outs.

\section{Conclusions}

All changes were in a clinically meaningful magnitude and sustainable for the full observation period. TRT seems to be an effective approach to achieve sustained weight loss in excessively obese hypogonadal men.
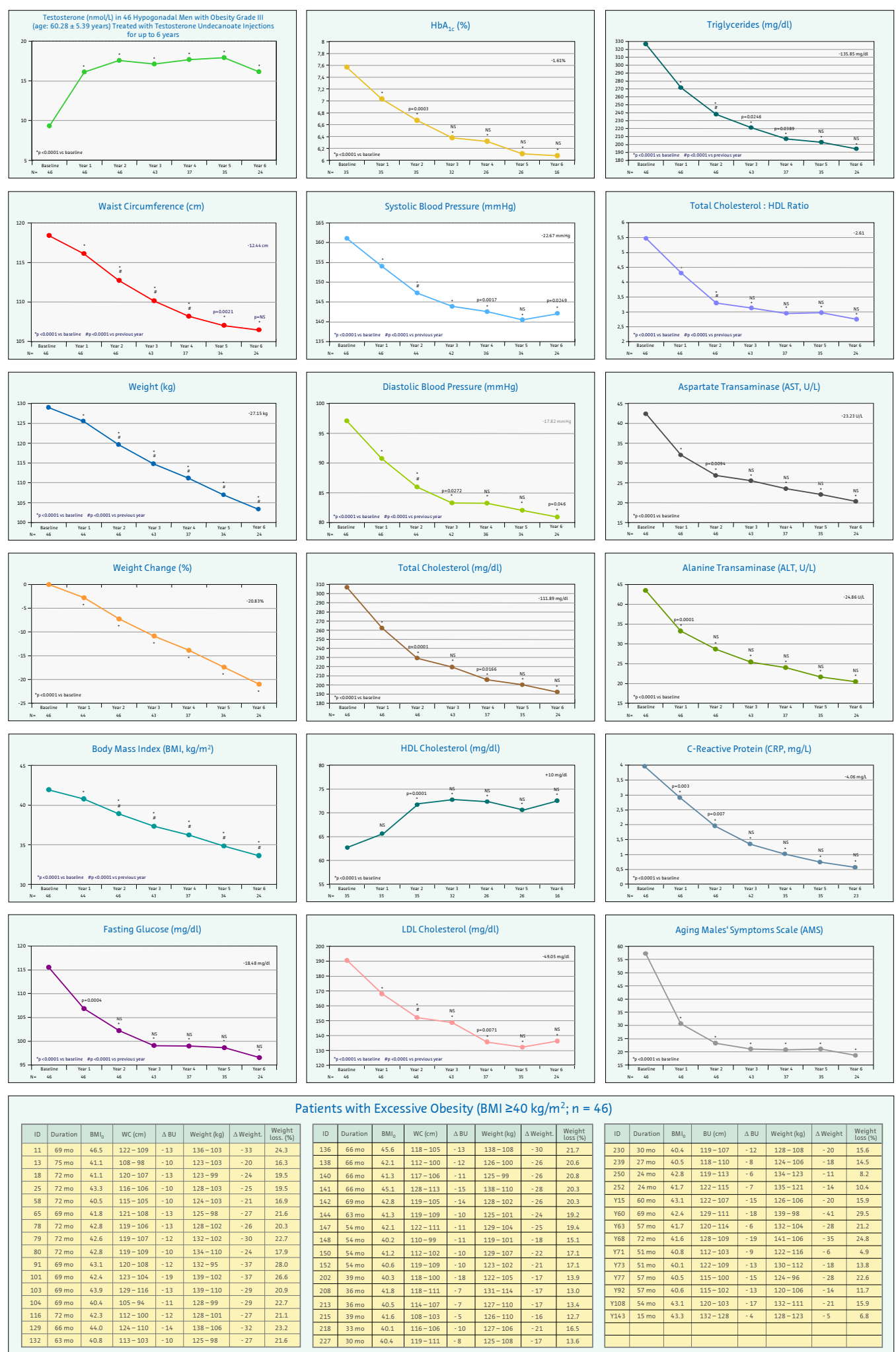

Patients with Excessive Obesity (BMI $\geq 40 \mathrm{~kg} / \mathrm{m}^{2} ; \mathrm{n}=46$ )
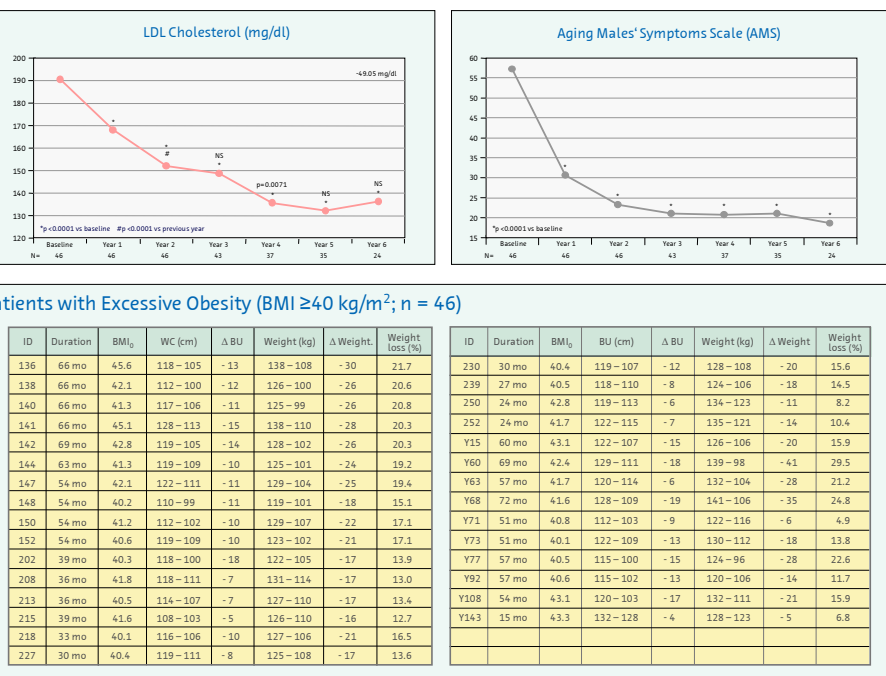